\begin{tabular}{|c|c|c|}
\hline \multicolumn{3}{|c|}{ A N N A L E S } \\
\hline UNIVERSITATIS & MARIAE C & \\
\hline \multicolumn{3}{|c|}{ LUBLIN - POLONIA } \\
\hline VOL. XXVII, 2 & SECTIO K & 2020 \\
\hline
\end{tabular}

Jagiellonian University. Faculty of International and Political Studies

\author{
MALGORZATA ABASSY
}

ORCID ID: https://orcid.org/0000-0002-9294-6156

AGATA KRZYWDZIŃSKA

ORCID ID: https://orcid.org/0000-0002-9301-7332

KATARZYNA KOSOWSKA

ORCID ID: https://orcid.org/0000-0003-1998-3812

\title{
Economic Security of the Russian Federation in the Light of Russo-Iranian Cooperation in the Face of Sanctions. Selected Aspects
}

\begin{abstract}
The paper sheds new light on the Russian Federation's economic security problem in the face of sanctions and changing geopolitical balance in Central Asia. The novelty of the research perspective and, subsequently, the results and conclusions are expressed by combining an economic perspective with a cultural-political and media-centered approach. There were analysed the range of Russo-Iranian economic cooperation, the factors that make Iran a prospective partner for Russia and the role of the Russian media in shaping the picture of friendly future in bilateral relations. The conclusions are that the Russian "turn to the South" - towards Iran - was provoked not only by the sanctions imposed which decreased the economic security level but it also resulted from the previously established patterns of the Russian foreign policy.
\end{abstract}

Key words: Russia, Iran, economic security, media, culture 


\section{INTRODUCTION}

The Russian Federation's economic security problem in the face of sanctions and changing geopolitical balance in Central Asia is analysed in the paper. The novelty of the research perspective and, subsequently, the results and conclusions are expressed by combining economic perspective with cultural-political and media-centered approach. The three main issues are discussed, namely: the range of Russo-Iranian economic cooperation, the factors that make Iran a prospective partner for Russia and the Russian media role in shaping the picture of friendly future in bilateral relations. The research question was the following: Was the Russian "turn to the South" - towards Iran - provoked only by the sanctions imposed that decreased the economic security level or was it a result of the previously established patterns of the Russian foreign policy, too?

Motivations for undertaking the research problem results from the similarity of Russia and Iran in terms of their political leadership and strategic partnership. Both countries have legal foundations of their political systems. Nevertheless, decisions and solutions are rooted in cultural patterns and mentality. Russian and Iranian presidents are elected in general elections but their power is supported and informally legitimized by trusted people and authority of a "strong man". The experts who hold the most important positions in military, economy and information sectors are also the ones from the closest presidential environment. The strategic Russo-Iranian partnership, in turn, is based on the common activities to weaken the position of the United States both in global and local perspectives. Pro-state mentality of the president of the Russian Federation and of the leaders of the Islamic Republic of Iran favors mutual cooperation.

The issues of economic security intertwined with cultural and mentality patterns and media influence on their strengthening are the new perspective on the problem of Russo-Iranian cooperation, which, so far, was discussed mainly from geopolitical and political perspectives. The research hypothesis that cooperation with Iran is aimed at increasing Russia's economic security and its influence in Iran is likely to be proved.

The research are based on hard data such as economic indicators and analysis of the variables concerning mainly oil and gas sales. The supportive and supplementary soft data are television programs contents, and cultural patterns analysis - mainly the state documents regarding leadership roles. Methodology of the research consists of quantitative analyses of economic data and qualitative analyses of the Russian media discourse and institutional dimension of bilateral cooperation, such as meetings of both leaders and international conferences. 


\section{ECONOMIC STABILITY OF THE RUSSIAN FEDERATION: THE PRESENT STATE}

There is no unequivocal and commonly accepted definition of "economic security" in literature on the subject. Nevertheless, most authors agree that economic security can be viewed as a set of internal (such as economic potential of a state, its macro-economic stability, and economic policy) and external factors (position of a state in the international environment) that affect economic situation of a country [Frejtag-Mika, Kołodziejak, Putkiewicz 1996: 28]. In the internal perspective, economic security is reduced to economic stability of a state.

Both international institutions and the Russian economists who estimate economic stability of the Russian Federation pay attention to the fact that its level decreased recently. The Global Competitiveness Report, of the World Economic Forum, presents a comparative analysis of economic development of countries and explores their economic stability. It is estimated by such indicators as: budget balance, public sector savings level, inflation ratio, the public debt level and rating of a country.

According to the data of Global Competitiveness Report from the years 20082016, macroeconomic stability of the Russian Federation decreased in the last 4 years. Initially, in 2011-2013, the economic stability of Russia tends to increase, which is recognized by the obtained scores - from 5.2 (2011) to 5.9 (2013) out of 7 . In addition, a higher position of Russia in global rankings in comparison with other states can be observed - an increase from $44^{\text {th }}$ position in 2011 to $19^{\text {th }}$ in 2013 , out of 140 analysed economies. In the following years, however, the indicators changed - in 2014, Russia was on $31^{\text {st }}$ position (5.5 scores), two years later, it was classified as $91^{\text {st }}(4.3)$ (Table 1). The data indicate that the level of economic stability and, as a consequence, economic security of the Russian Federation decreased [Falkowski 2015: 153-172].

Table 1. Macroeconomic environment of the Russian Federation (2008-2016)

\begin{tabular}{|l|c|c|c|c|c|c|c|c|c|}
\hline \multicolumn{1}{|c|}{ Year } & 2008 & 2009 & 2010 & 2011 & 2012 & 2013 & 2014 & 2015 & 2016 \\
\hline Scores & 5.6 & 5.5 & 4.5 & 5.2 & 5.8 & 5.9 & 5.5 & 5.3 & 4.3 \\
\hline Place & 29 & 36 & 79 & 44 & 22 & 19 & 31 & 40 & 91 \\
\hline
\end{tabular}

Source: The Global Competitiveness Report, World Economic Forum, 2008-2016.

Research of Russian economists (among others, members of the Russian Academy of Sciences, RAN), who estimated the level of economic security of the country by referring to 18 indicators, revealed similar results. The indicators were the following: production growth, condition of the federal budget, level of indebtedness of the state, the proportion of citizens with income below social minimum, the ratio of the income of $10 \%$ richest to the $10 \%$ poorest [Strukov, Slepokurova 2017: 238-252]. 


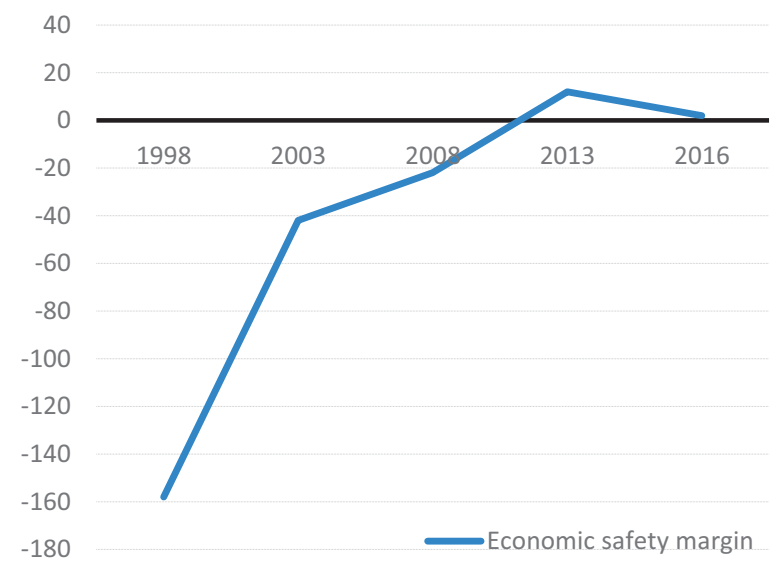

Figure 1. Economic safety margin for the Russian Federation (1998-2016)

Source: Strukov, Slepokurova [2017: 238-252].

In 1998-2013, the aggregate level of Russia's national security tends to grow. In 2013 , in turn, the period of rapid decrease in the level of safety started - from 12 to 3 scores (Figure 1).

\section{DECREASE IN THE LEVEL OF ECONOMIC SECURITY OF THE RUSSIAN FEDERATION - CAUSES}

The high level of economic stability and, as a result, economic security of the Russian Federation resulted from high oil prices in world markets. It was due to the fact that the income from export sales of energy (oil mostly) makes the main part of the Russian federal budget income - about 50\%. Energy industry has been the foundation of the Russian economy.

In 2000-2008, an average oil price increased from USD 27 (2000) to USD 94 (2008) for a barrel. That was a uniquely favourable time for Russian economy: oil and oil products export income increased from USD 36.2 billion in 2000 to USD 241 billion in 2008. Gross domestic product (GDP), in turn, increased by about $8 \%$ a year and only in 2010-2013, it slightly slowed down [GDP growth... 2019]. In 2014, however, negative dynamics of Russia's GDP was recorded which was tantamount to the decline in the country's economic stability [GDP growth... 2019].

The decrease was a consequence of a drop in oil prices in the world markets. In 2014-2015, it was from USD 98 to USD 54 for a barrel. There is a high correlation between oil price and Russia's GDP - 0.98 ( $\max$ is 1.0 ), and therefore it is obvious that low oil prices affected the whole Russian economy. 


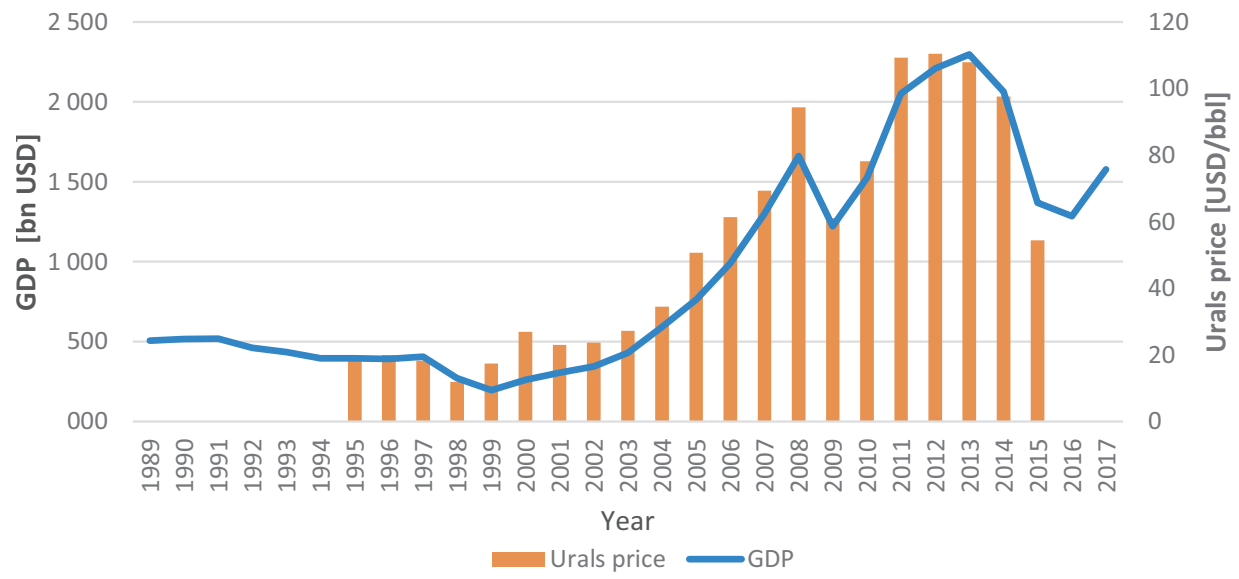

Figure 2. Urals crude oil price vs. Russian GDP in the years 1989-2017

Source: Neft' sovremennoy Rossii: +/- 20 let, "Neftegazovaja Vertikal” vol. 21, p. 9 [2015].

GDP (current US\$) - Russian Federation, World Bank Data, 8 November 2019, https://data.worldbank.org/indicator/ NY.GDP.MKTP.CD?locations=RU (access: 09.07.2020).

Thus, maintaining low oil prices (USD 25-40 for a barrel) is the main threat to Russia's economic stability. The economic downturn, the outflow of capital, a decrease in investment activity, increased inflation and a drop in real wages combined with an increase in the unemployment rate were the derivatives of the low oil prices.

\section{GEOPOLITICS AND RUSSIA'S ECONOMIC SECURITY}

Together with direct economic causes that affect economy conditions, some geopolitical factors, as well as relations with the near and far neighbourhood have to be taken into account. They stabilize or destabilize country's economic security to a great extent.

Russia has been strengthening its international position on the basis of energetic potential since the beginning of the $21^{\text {st }}$ century. As the main supplier of oil and gas to the EU market it makes effort to maintain good relations with the most important EU member states. It was due to the inflow of investments from the West and constant economic cooperation. The above-mentioned inflow of investments to the Russian energy sector was necessary because the previously exploited oil-gas fields were mostly depleted [Korzhubaev, Jeder 2010: 14-20]. In order to maintain the extraction of oil and gas at the present level and to guarantee economic stability, Russia has to develop non-traditional Arctic fields that have complex geological structure. Realisation of those highly capital-consuming projects has been possible only when foreign investments are utilized [Suprunenko et al. 2014: 26-33]. 
Russia's energy policy towards the other weaker EU member states and the former Eastern Bloc countries was getting more and more assertive every year. As a result, crude oil and natural gas are often used by Russia as a bargaining chip in relations with those countries.

\section{RUSSIA'S ECONOMIC SECURITY UNDER SANCTIONS}

Due to the Ukrainian conflict, that ended with the Crimean annexation, the political situation became less stable. After the events in 2014, the USA and the EU imposed sanctions on Russia: American and European companies were prohibited to cooperate with Russian energy companies, to supply equipment for work in the Russian part of the Arctic, on the continental shelf, in the fields with unconventional reserves and shales. All kinds of services for the projects were also banned. The U.S. sanctions were imposed on all the biggest Russian oil companies - Gazprom Neft, Lukoil, Surgutneftegas, Rosneft, Transneft, or Gazprom. EU sanctions did not include gas industry which was the consequence of the fact that the EU market depends on Russian gas supplies to a greater extent than in the case of oil sector.

The long-lasting and successively prolonged western sanctions effectively hampered the process of developing fields in new prospective regions of the country. Consequently, the biggest country's oil company Rosneft and also some other Russian companies lost financial and technological support of their key foreign partners [Kutuzova 2018: 18-12].

The American concern ExxonMobil, by the decision to stop its activity in Russia, caused the greatest damages in Russian oil industry. Cooperation agreement between ExxonMobil and Rosneft (2013-2014) involved implementation of 10 common projects, such as research and exploitation on the Black Sea shelf, in the Arctic and Western Siberia. As a result of the sanctions, the American oil giant abandoned nine out of the commonly realized projects [ExxonMobil... 2014]. In this situation, Rosneft halted the capital-consuming projects on the Arctic shelf till the lifting of the sanctions.

Following the U.S. sanctions imposed on Russia, European companies also have to obey the restrictions. Shell cancelled exploitation of the Bazhenovsky fields in Khanty-Mansi Autonomous Okrug and the British BP halted the project which had been realized with Rosneft in Orenburg Oblast in Western Siberia. As a result of the sanctions, newly started cooperation between Lukoil and Total was broken. In May 2014, both companies agreed to set up a joint venture company in order to exploit Bazhenovsky fields in three concession areas of Western Siberia [Total... 2015].

According to estimations, the sanctions affected about $90 \%$ of operations in the Russian oil industry. Russian companies lost access to the imported technologies and equipment which were necessary to exploit the shelf or non-traditional oil-gas fields. Proportion of the imported equipment in the Russian oil sector hesitated from 
$50 \%$ in the unconventional reserves segment to $80 \%$ in the LNG segment and shelf exploitation.

Experts estimates that western sanctions can paralyze about one fourth of the Russian oil sector and bring about the decrease in oil exploitation to 32 million tonnes every year in the mid-term perspective and to 100 million tonnes - in the long-term perspective. If the sanctions are prolonged, the decrease tendency will become more and more obvious every following year. Moreover, the Russians themselves admit, nowadays geopolitical sanctions result in losses of USD 40 billion every year, which causes a decrease in the level of economic stability [Hartukov 2018: 4-10].

Therefore, the extension of sanctions imposed by the West on Russia, may result in a decrease of economic security of the state in the mid- and long-term perspective.

\section{RUSSIA'S “TURN TO THE EAST”: IDEOLOGICAL AND POLITICAL PERSPECTIVES}

The West has been important for Russia not only in the perspective of economy, including economic safety and policy, but also in terms of identity, which is expressed implicite as the imperial one and the identity of superpower. Russia wanted to play a significant role in shaping the European political order and that striving was satisfied many times: Congress of Vienna (1815), Treaty of Versailles (1919), Tehran - Yalta - Potsdam Conferences (1943-1945). Those periods of glory were interrupted by conflicts with European powers and, in consequence, Russian turn towards the East. Nowadays, these are not European countries, but the USA that is the main rival for the Russian Federation. Nevertheless, the mechanism of seeking solutions by turning to the countries to the east and south of Russia's borders has remained unchanged.

To explain the reasons for the present change of the vectors in Russian policy, experts point to three aspects: lack of the possibility to demonstrate Russia's influence in rivalry with the USA in the international arena, continuity of the $19^{\text {th }}$-century paradigm which places Russia between the West and the East; the response to economic development of Asian countries, especially China. The latter reason makes Asian countries a prospective partner of Russia. Nevertheless, it is worth remembering that the reasons for "turn to the East" are not solely of an economic character, nor do they stem from the coherent state policy.

[...] even now a part of the elitès is afraid of the "turn to the East", because they associate it with giving up European civilisational identity and they stay comfortably in a constant, although obsolete, system of landmarks, where Europe is associated with progress, Asia and Eurasia - with marginal, superpower's Eurasianism. [Karaganov, Makarov 2017] 
It is enough to trace back Russian history and the geopolitical concepts rooted in culture and mentality to conclude that the Russian Federation recognizes itself as a partner in political games with European countries and the USA, whereas the East is used as a tool in struggle for power and reinforcement of the state's security at different levels. One of them is economic safety focused mainly on energy safety.

Leonid Kozlov shares the opinion that the Russian "turn to the East" was provoked by the international situation and it has a rather tactic than strategic character [Kozlov 2016]. Russia's tactic partnership with China and Iran results from the problem all three countries have in terms of shaping satisfactory relations with the USA. Since the Ukrainian crisis in 2014, Russia's relations with the EU countries and the USA deteriorated. That situation led Russian political elites to turn to the South - the direction which has been a traditional vector of territorial, economic and political expansion from the times of Tsar Peter I. All the vectors are interrelated although in every historical period one of them tends to be in the first place. One can assume that without taking into account the cultural context, the conclusions will be misleading. Thus, each economic activity has its ideological background and it is aimed at broadening and strengthening influence on a territory. Consequently, strengthening Russia's economic safety by its cooperation with the Islamic Republic of Iran is, at the same time, an effort to broaden Russia's influence in this country, realize Russia's interests and protect its state identity.

\section{“TURN TO THE SOUTH”: BETWEEN COOPERATION AND RIVALRY}

Two vectors are present in Russia's politics towards Iran: striving for cooperation and creating the role of Iran's partner in regional security policy versus treating Iran as a tool in the Russian game with the USA in the struggle for influence in Central Asia. Those vectors are often complementary but, even more frequently, they are separate.

For Russia, Iran is the only partner with whom multi-dimensional partnership is possible due to common areas of influence, two centuries of shared history, great significance of both countries in the region, similar styles of governing and ease of communication conditioned by mentality. The last factor is often underestimated in political science experts' reports. The foundation for cooperation, which results from political interests and which is rooted in mentality, has played an equally great role in both countries. According to experts, the present Russo-Iranian cooperation has reached the unprecedented level and it tends to grow. The fact was also stressed by Iranian President Hassan Rouhani at the meeting in Sochi, on 22 November 2017: "I am happy that in the last year, relations between our countries were good. And our cooperation had positive character not only in bilateral but also in regional and international dimensions" [Vstrecha... 2017].

In 2013-2014, President Vladimir Putin and President Hassan Rouhani met four times: on 13 September 2013 at the Forum of the Council of Heads of States of 
the Shanghai Cooperation Organisation in Bishkek; on 21 May at the Conference on Interaction and Confidence-Building Measures in Asia (CICA) in Shanghai; on 12 September 2014 at the Council of Heads of States of the Shanghai Cooperation Organisation in Dushanbe, and on 29 September 2014 at the $4^{\text {th }}$ Caspian Summit in Astrakhan. A series of meetings was continued in 2015-2018. Energy security was the subject of conversation during numerous meetings, either as declarations or as working out strategies. At a press conference, Putin said:

We talked about cooperation in the energy sector. All three countries have good oil-gas resources and they have a unique regional and international location. We talked about cooperation in oil and gas exploitation technology industry. We also talked about investments into the energy sector, which play an important role for our countries. [ $\mathrm{Za}$ javlenija dlja pressy po itogam vstrechi Vladimira... 2017]

Another tripartite meeting, this time between Vladimir Putin, Hassan Rouhani and Turkey's President Recep Tayyip Erdoğan, focused on finding a solution to the Syrian conflict. At press conferences, the leaders stressed significance and efficiency of the worked out solutions and they declared further cooperation aimed at maintaining stability in the region [Vstrecha ... 2017].

Economic relations, including energy security issues, were incorporated into a wider context of inner integrity of the countries, which was understood as policy transparency and respect for the values expressed implicite. The motivations for strengthening cooperation in economic and oil gas industry sectors are clear. Nevertheless, the strivings of political character may disturb them. Thus, an assumption has to be made that the market economy is determined by political decisions of the heads of the states and the latter ones result from the struggle for power in the region.

Safety issues play a substantial role in building the economic cooperation strategy. They require consideration of political interests, both Russian and Iranian. The problem of Syria, namely its post-war order, is in the foreground. At the beginning of cooperation with regard to the post-war order in Syria, Moscow's and Tehran's positions were convergent. However, it has changed. Russia starts to criticize Syrian President Bashar al-Assad and would expect some quality changes in Syrian society in order to prevent such events like the Arab Spring. Iran opposes to such move. Concerning the post-war order in Syria, Russia's perspective is close to the USA's expectations, which concerns Iran. In Iranian mentality the pattern is activated that Russia one more time sacrifices its relations with Iran to strengthen relations with the USA. Moreover, in contrast to Iran, Russia has long experience in the field of diplomatic games and negotiations with the Western countries. With reference to the Syrian problem, knowledge of the regional specificity and Shiite mentality, or more generally of the country's Islamic society, would favor Russia's partnership with Iran. However, striving for the establishment of Islamic democracy in Syria is contrary to the intentions and interests of both Russia and the Western countries. 


\section{POLITICAL FACTORS CONDUCIVE TO ECONOMIC COOPERATION}

Both the Russian Federation and Iran have been the subjects of U.S. confrontational policy. Such an opinion has been confirmed by the following facts: on 7 April 2018, 38 representatives of the Russian business and policy were included into the list of people subject to sanctions - there were also some big companies among them, such as Rosoboronexport; on 11 April 2018, President Donald Trump tweeted about U.S. readiness to intervene in Syria because of an alleged attack with chemical weapons use and the burden of it was on Russia and Iran; a new project of sanction appeared on the U.S. Congress website and it assumed that Russia would be disconnected from the international banking system. Valery Solovjov, a historian in the Moscow State Institute of International Relations, claims that within 1-1.5 years, American activities would have a systemic character (instead of temporary), in order to put pressure and force Russia to modify its domestic and foreign policy.

There are many factors that make Iran an attractive and perspective partner for Russia. First of all, it has a large and well-trained army made up of 350,000 soldiers. It consists of the Islamic Revolutionary Guard Corps and al-Quds formation who are known for their devotion to Islamic revolution ideals and their mission is to protect, preserve and propagate them. Moreover, Iran is a Shiite country which has an influence on Shiite communities in other Muslim countries, such as Iraq, Syria, Libya, Yemen, Afghanistan, Bahrain. It also has an important position in the region due to its proximity to the Caucasus countries, Afghanistan and Pakistan.

With regard to economic cooperation, Iran has huge resources of oil and gas (about $34,000 \mathrm{~m}^{3}$ ). In this respect, it ranks second, behind Russia. Due to the lack of infrastructure, and hence limited possibilities of extraction and transmission of oil, Iran becomes a potential market for Russia. Iran also has significant human resources which increases its economic potential: at present, Iran's population is about 80 million people, $49 \%$ of whom are of working age [Iran Demographics Profile 2018]. As for non-political and non-economic factors, it is worth remembering that Iran has a long tradition of strong central power which helps to communicate with Russia on the mental level. Pragmatism in actions is supported with trust credit in the situations were a precise calculation of gains and losses is impossible.

The above-mentioned qualities make Iran one of the most influential countries in the region and an important player in Central Asia.

\section{THE RUSSIAN FEDERATION IN IRAN'S ENERGETIC SECTOR}

Russia played a considerable role in the settlement of the issue of the Iranian "nuclear question". After the sanctions had been lifted, new opportunities for reinforcement economic cooperation occurred. It referred to many areas, including oil and gas sectors. In November 2017, the "oil for goods" project was initiated. 
According to the agreement, Moscow agreed to buy Iranian oil, while Iran would use half of the payments received from Russia to buy and import its goods. From 2018 onwards, Russia plans to buy 5 million tonnes of Iranian oil per year. Russian Trade Representative in Iran, Andre Luganski, declared that Russia may export goods worth USD 45 million under the "oil for goods" project. The project, however, does not accept the supply of weapon as a commodity.

Many Russian companies, such as Gazprom, Rosneft, Gazprom Neft, Zarubezhneft, Tatneft, Lukoil, hold conversations concerning oil exploitation in Iran. Some other energy companies negotiate agreements concerning project implementation, extraction and processing of oil and natural gas (liquefied natural gas, LNG), transmission pipelines, industry, or petrochemicals. The Russian state-controlled company Zarubezhneft demonstrates a particular interest in the oil extraction project in Iran. The Rosgeology holding declares its readiness to provide maintenance services for Iranian partners. Technopromexport, in turn, intends to participate in the projects of building oil and natural gas processing plants, and to provide the services concerning oil and gas field development. Moreover, West Siberian Oil and Gas Company is interested in the projects of development and exploitation hydrocarbons in Iranian fields. Power engineering is also a perspective direction of Russo-Iranian cooperation. It concerns, inter alia, reconstruction of old power plants, construction of new ones, and participation in the nuclear energy development.

\section{RUSSIAN MEDIA ABOUT RUSSO-IRANIAN COOPERATION}

Economic Russo-Iranian cooperation is a subject of analyses and comments in most Russian media. Russia-24 (Rossiya-24) and Channel One (Pervyy kanal) can be regarded as the most representative. They have the biggest range and viewership [Brandmedia 2020]. Three topics enjoyed the greatest interest, namely sanctions imposed on Iran, nuclear energy (Bushehr Nuclear Power Plant) and power engineering. In the information services of most TV stations it was stressed that new agreements concern the construction of two nuclear units in the Bushehr Nuclear Power Plant. It was agreed that Russia would supply nuclear fuel and it would also deal with its utilization as Iran does not have appropriate technologies [Rossija postroit... 2014]. It was decided that some new nuclear units, called "Bushehr 2", would be built in subsequent years. Moreover, Russia committed to train the Iranians within the frames of cooperation [Rossija postroit... 2014].

Russia-24 broadcast a report devoted to the Bushehr Nuclear Power Plant entitled Atom Irana. Spetsial'nyy reportazh Pavla Orlova [Orlov 2015] (Eng.: Atom of Iran. A Special Report by Pavel Orlov). The journalist's report on his visit to the power station explains in details Russo-Iranian relations that date back to the 1990s. The construction of the plant was initiated in 1974 by German companies. It was to be the first nuclear power plant in the Near East but its construction was interrupted by 
the revolution of 1979. Moscow and Tehran discussed the issue again in 1992. Then an agreement for the use of nuclear energy for peaceful purposes was signed. It took a long time before some technical changes in the German project were introduced, and chilled water required in the power plant, was brought from the Persian Gulf [Orlov 2015]. The cooperation between Iran and Russia was held in a good atmosphere; the Iranians acquired a good knowledge of Russian vocabulary (technical terms). What is more, differences in terms of religion did not form any barrier to mutual cooperation [Orlov 2015]. Kiril Komarov, the first deputy CEO of Rosatom, stressed the fact that the activity of the state-owned company abroad brought huge benefits for the country: "[...] we think of Russia's interests first. Every power plant construction abroad brings a huge effect for the Russian economy. These are tens of thousands of workplaces, these are billions of dollars of income to budget from taxes" [Orlov 2015].

On 11 September 2016, Channel One announced that the "Bushehr 2" project was initiated. Its investment value is measured in billions of dollars and the second and third units are planned to be completed in 2024 and 2026. The power generation capacity of the Bushehr plant is 1,000 MW and in the case of two new units $-2,100$ MW [Rossija i Iran ... 2016]. Both sides regard the project as a matter of pride because they succeed to combine the contemporary technologies and equipment with the old German project. In the long-term perspective it is planned to construct eight units [Rossija i Iran ... 2016].

\section{LIFTING OF SANCTION FOR IRAN: NEW PERSPECTIVES AFTER YEARS OF RESTRICTIONS}

Suspension of the economic and financial sanctions against Iran affected also energy industry. When the long-standing conflict concerning the Iranian nuclear program was over, Russia-24 called the $16^{\text {th }}$ January 2016 a "holiday" and this fact was recorded by all Iranian newspapers [Osvobozhdennyj... 2016]. The achieved agreement resulted from the fulfillment of international obligations by Iran. Thanks to that, the country could return to the world market. President Rouhani commented on the event in public: "Atom agreement with the world powers starts a gold page in our country's history. What has been achieved is the whole nation's victory" [Osvobozhdennyj... 2016].

Russia-24 journalists described the event as a historical one. In short TV material, which summed up the "previous Iranian experience of sanctions", they mentioned that the first sanctions were imposed by the USA in the 1970s [Osvobozhdennyj... 2016]. It was recalled that in 2005, Mahmud Ahmadinejad, who strongly believed that Iran needs to develop nuclear energy, became president of the country. Consequently, in 2006, the United Nations imposed sanctions on Iran for developing the nuclear program [Osvobozhdennyj ... 2016]. Only after Hassan Rouhani became president, an agreement was signed that Iran freezes some aspects of its nuclear program in 
exchange for partial lifting of sanctions. Iran agreed to reduce its reserves of enriched uranium to $20 \%$ [Osvobozhdennyj... 2016].

On 28 March 2017, an official visit of President Rouhani in Moscow took place. He met Vladimir Putin and they signed documents concerning, among others, energy and technology spheres [Davydov 2017]. In the news service Vesti, on Russia 1, the visit was estimated as bringing mutual relations to a new level. In the conversation with Rouhani, Putin said that the up-to-present cooperation was very good: "Iran is our good neighbor and a reliable partner. It is enough to say that the last year's exchange of goods between our countries increased by $70 \%$ which is a specific phenomenon in difficult circumstances" [Davydov 2017].

\section{REINFORCEMENT OF RUSSO-IRANIAN COOPERATION WITHIN “BUSHEHR 2"}

Russia-24 refocused on the subject of power plant construction at the end of October 2017. Special correspondent of the station, Olga Bashmarova, prepared material about Iran. The construction had to be preceded by strengthening and stabilization of the area due to the fact that Iran is in the region of great seismic activity [Bashmarova 2017]. Iran has an extremely high level of energy consumption and this conclusion results from the opinions included in the program. Vice-president Ali Akbar Salehi estimates that the country's energy demands are higher than is currently the case: "[...] Iran needs 20 thousand megawatts of electricity. It can be produced by 20 such units. It is obvious that such a number of power plants requires huge investments" [Bashmarova 2017].

A manager of the Bushehr unit paid attention to the fact that for the Iranians, Russia's engagement in the Iranian peace program, at a time when the whole world was against it, was very important [Bashmarova 2017]. The new reactor had to meet safety requirements after the Fukushima accident. Both countries' cooperation within its frames went smoothly: the Bushehr Power Plant operates properly, its staff was trained in Moscow, they speak fluent Russian. However, they are not allowed to give interviews and to be camera-recorded due to safety reasons [Bashmarova 2017].

Energetic cooperation is inevitably connected with great politics and therefore energy security issues were again discussed on 1 November 2017 at the Tripartite Summit in Tehran where President Rouhani, President of Azerbaijan Ilham Alijev, and Russian Minister of Energy Alexander Novak met [Suvorova 2017]. Commenting on the meeting with the Iranian representative, Minister Novak stressed that energetic cooperation of both countries concerns not only the very important Bushehr plant but also a power plant in the southern part of Bandar Abbas. At present, Russian company Technopromexport participates in the latter project [Suvorova 2017]. At ministerial meetings, a planned project of "energetic bridge" connecting the three countries was discussed. Minister Novak, when he was asked about the issue, explained common plans in detail: 
Two directions for connecting energetic systems of Russia and Iran were discussed. The first one through Azerbaijan: Russia - Azerbaijan - Iran. The second one is through Russia - Georgia - Armenia - Iran. [...]. To make the final decision about the integration of electro-energetic systems, it is necessary to conduct technical and economic research. Now we have created two working teams who prepare technical conditions of the electro-energetic systems connection. Generally, I think that it can bring an effect, which is positive for the countries participating in the process because each of the countries has different needs. For example, in Iran, the peak consumption period is in the summer, whereas in the winter, demand for energy is lower. In Russia, it is different: the peak consumption period is in the winter when temperatures are low. Therefore, in this part it is possible to achieve synergy from the point of view of efficient power placement and transfer the energy surplus when it is not required. [Jamshhikov 2017]

\section{RUSSIAN TV COMMENTS}

Russo-Iranian cooperation in the energy sector has been positively presented and commented in media for the last several years. An increase in trust at the highest political and diplomatic level was reflected in the opinions of the Russian state TV commentators who, preserving the Russo-centered point of view, expressed a positive assessment of Russia's political and economic interests. In that context, the relations with the USA, whose picture has many negative and pejorative features, are at the opposite pole. It seems that the dynamics of Russo-Iranian relations was aptly expressed by the final conclusion in the comment of Bashmarova: "There is a great future in the Russo-Iranian relations sphere" [2017].

\section{CONCLUSIONS}

The Russian state television provided its audience with detailed information on the progress in cooperation with Iran, which was caused by great interest in the ally partner. The knowledge of the Russian was broadened by coverages of Iran. All that helped to create a positive image of the southern partner and made the Iranians more familiar with the Russian people. This way, public support for the state activities and president's decisions was built and strengthened.

The research hypothesis was positively verified: Russo-Iranian relations, especially from the point of view of strategic partnership and Russia's economic security, are going to develop regardless of temporary differences. Iran has been an important strategic partner for Russia not only in terms of energy security but also due to the preservation of stability in the region. Strengthening of economic cooperation is supported by the fact that the Russian business elites are closely linked with the state political elites. In the situation when U.S.-Russian relations have been weakened 
and in the Russian politicians' speech the Cold War rhetoric is often heard again, Russo-Iranian cooperation includes, inter alia, widely understood economic and energetic security, Russian borders security. The question arises: will Russia choose Iran as its strategic partner or will it restrict itself to tactic partnership, as in previous years. The USA's attitude towards Russia is still a decisive factor.

Meetings of both countries' leaders, numerous agreements signed between Russian and Iranian companies allow us to suppose that power engineering is just the first stage of the two states' cooperation in the economic sphere. Russian media inform about further and broader cooperation in the oil and gas sector, reflecting the present state and preparing basis for future partnership. The subject requires further profound analyses.

On 5 November 2018, the USA imposed sanctions on Iran's energy sector. Moreover, the USA required Iran to withdraw entirely from its nuclear program. The Russian state TV stressed that the leading European countries, such as Germany, France, Great Britain and other EU countries deeply deplore this fact $[S \operatorname{Sh} A \ldots$ 2018]. Brussels stated that, despite the American sanctions, it is going to broaden its cooperation with Iran. The sanctions affected both companies and ordinary people who protested in Tehran's streets [Vstupili... 2018].

In addition, the Russian Federation became the subject of repressive actions by the EU and the US. Let us remind that in 2014-2018, limited access to foreign loans, a ban on imports of the energy equipment were among the most severe sanctions put on Russia. The sanctions imposed on Iran and Russia create a fertile ground for strengthening both countries' cooperation. Supporting the region's stability and preventing U.S. interference is another decisive factor.

\section{BIBLIOGRAPHY}

Bashmarova, O. 2017. Faktor doverija. Special'nyj reportazh, "Vesti”, 4 November, https:/www.vesti.ru/ videos/show/vid/735299/ (access: 09.07.2020).

Brandmedia. 2020. Rejtingi telekanalov, http://www.brandmedia.ru/serv_idP_51_idP1_68_idP2_2425. html (access: 09.07.2020).

Davydov, D. 2017. Rossija i Iran vyshli na novyj uroven' sotrudnichestva, "Vesti", 28 March, https://www. vesti.ru/doc.html?id=2871293 (access: 09.07.2020).

ExxonMobil svernula 9 iz 10 proektov s «Rosneft'ju», "Vedomosti”, 30 September 2014, https://www.vedomosti.ru/business/articles/2014/09/30/exxonmobil-svernul-9-iz-10-sovmestnyh-proektov-s-rosneftyu (access: 09.07.2020).

Falkowski, K. 2015. Bezpieczeństwo ekonomiczne Rosji w warunkach sankcji gospodarczych UE w kontekście posiadanych międzynarodowych przewag konkurencyjnych, "Studia Europejskie", vol. 4(1), pp. 153-172.

Frejtag-Mika, E., Kołodziejak, Z., Putkiewicz, W. 1996. Bezpieczeństwo ekonomiczne we wspótczesnym świecie, Wydawnictwo Politechniki Radomskiej, Radom.

GDP (current US\$) - Russian Federation, World Bank Data, 8 November 2019, https://data.worldbank. org/indicator/NY.GDP.MKTP.CD?locations=RU (access: 09.07.2020). 
GDP growth (annual \%) - Russian Federation, World Bank Data, 8 November 2019, https://data.worldbank. org/indicator/NY.GDP.MKTP.KD.ZG?locations=RU (access: 09.07.2020).

Hartukov, E. 2018. Nesostojatel'nost' zapadnyh mifov, "Neft' Rossii”, vol. 9(1), pp. 4-10.

Iran Demographics Profile. 2018, https://www.indexmundi.com/iran/demographics_profile.html (access: 09.07.2020).

Jamshhikov, A. 2017. Novak: Rossija i Iran gotovjat novye krupnye kontrakty, "Vesti", 22 February, https:// www.vestifinance.ru/articles/81765 (access: 09.07.2020).

Karaganov, S., Makarov, I. 2017. Rossijskij povorot na Vostok, Rossija w globalnoy politikie, "Russia in Global Affairs", 27 December, https:/globalaffairs.ru/global-processes/Rossiiskii-povorot-naVostok-19272 (access: 09.07.2020).

Korzhubaev, A., Jeder, L. 2010. Inostrannye investicii: prosto my ne umeem ih gotovit', "Neftegazovaja Vertikal”, vol. 19(1), pp. 14-20.

Kozlov, L. 2016. Povorot Rossii na Vostok - illjuzija geopoliticheskogo vybora, 21 April, https://primamedia. ru/news/500879/ (access: 09.07.2020).

Kutuzova, M. 2018. Tochechnye udary. Neftegazovaja promyshlennost' Rossii ispytyvaet na sebe davlenie novyh amerikanskih sankcij, "Neft' Rossii", vol. 6(1), pp. 8-12.

Neft' sovremennoy Rossii: +/- 20 let, "Neftegazovaja Vertikal" 21, 2015, p. 9.

Orlov, P. 2015. Atom Irana. Special'nyj reportazh Pavla Orlova, "Rossija-24", 26 September, http://vefire. ru/news/Vesti-AtomIrana-SpecialnyjjreportazhPavlaOrlova/ (access: 09.07.2020).

Osvobozhdennyj ot sankcij Iran vyhodit na neftjanoj rynok, "Vesti", 18 January 2016, https://www.vesti. $\mathrm{ru} / \mathrm{doc} \cdot \mathrm{html}$ ?id=2709202 (access: 09.07.2020).

Rossija i Iran pristupajut k stroitel'stvu AES «Busher-2»", "Pervyy Kanal”, 11 September 2016, https:// www.1tv.ru/news/2016-09-11/309716-rossiya_i_iran_pristupayut_k_stroitelstvu_aes_busher_2 (access: 09.07.2020).

Rossija postroit v Irane dva novyh bloka AES Busher', "Vesti” 11 November 2014, http://www.vesti.ru/ doc.html?id=2116042 (access: 09.07.2020).

SShA v polnom ob"eme vosstanavlivajut sankcii v otnoshenii Irana, "Pervyy Kanal", 3 November 2018, https://www.1tv.ru/news/2018-11-03/355067-ssha_v_polnom_ob_eme_vosstanavlivayut_sanktsii_v_ otnoshenii_irana (access: 09.07.2020).

Strukov, G.V., Slepokurova, J. 2017. Ekonomicheskaya besopasnost' Rossiyskoy Federatsii sovremennoye sostojaniye, uroven' i ugrozy, "Vestnik VGUIT", vol. 3(1), pp. 238-252.

Suprunenko, O., Suslova, V., Medvedeva, T., Stojanov, S. 2014. Obratnaja storona shel'fovogo monopolizma, "Neft' Rossii", vol. 9(1), pp. 26-33.

Suvorova, A. 2017. Prezident Vladimir Putin pribyvaet v Tegeran, 1 November, https://www.vesti.ru/videos/ show/vid/734921/cid/6 (access: 09.07.2020).

Total bez svity. Francuzy ostavili trudnoizvlekaemuju neft' LUKOJLu, “Kommersant”, 25 June 2015, https:// www.kommersant.ru/doc/2754062 (access: 09.07.2020).

Vstrechas Prezidentom Irana Hasanom Ruhani, 22 November 2017, http://kremlin.ru/events/president/ news/56154 (access: 09.07.2020).

Vstupili v silu novye amerikanskie sankcii protiv Irana, "Pervyy Kanal", 5 November 2018, https://www.1tv. ru/news/2018-11-05/355136-vstupili_v_silu_novye_amerikanskie_sanktsii_protiv_irana (access: 09.07.2020).

Zajavlenija dlja pressy po itogam vstrechi s Prezidentom Irana Hasanom Ruhani i Prezidentom Turcii Redzhepom Tajipom Jerdoganom, 22 November 2017, http://kremlin.ru/events/president/news/56153 (access: 09.07.2020).

Zajavlenija dlja pressy po itogam vstrechi Vladimira Putina, Prezidenta Irana Hasana Ruhani i Prezidenta Azerbajdzhana Il'hama Alieva, 1 November 2017, http://kremlin.ru/events/president/transcripts/55984 (access: 09.07.2020). 


\section{BIOGRAPHIES}

Malgorzata Abassy, an Associate Professor at the Jagiellonian University in Kraków, $\mathrm{PhD}$ with habilitation in the field of cultural studies. She works at the Institute of Russian and East European Studies, Faculty of International and Political Studies. Her research focuses on the problem of intelligentsia and international relations between Russia and Poland, and between Russia and Iran. She has five monographs published: Modernizacja w cieniu Allaha. Wspótczesny Iran (Kraków 2019), Russian Mason on the Paths of His Native Culture. The Case Study of Nicolas Novikov (Kraków 2015), Kultura wobec postęu i modernizacji: Rosja i Iran w perspektywie porównawczej (Kraków 2013), Irańska inteligencja w XIX wieku i Rewolucja Konstytucyjna (1905-1911) (Kraków 2010), Inteligencja a kultura. O problemach samoidentyfikacji dziewiętnastowiecznej inteligencji rosyjskiej (Kraków 2008). She is also the author of several dozens of scientific papers on the history of Russian, Polish and Iranian cross-cultural relations. E-mail: malgorzata.abassy@uj.edu.pl

Katarzyna Kosowska, an Assistant Professor at the Institute of Russian and East European Studies, Faculty of International and Political Studies of the Jagiellonian University in Kraków. Her research focuses on the economies of the countries of the Eurasian region, economic and energy security of Russia and post-Soviet countries. E-mail: katarzyna1kosowska@uj.edu.pl

Agata Krzywdzińska, $\mathrm{PhD}$, an Assistant Professor at the Institute of Russian and East European Studies, Faculty of International and Political Studies of the Jagiellonian University in Kraków. She conducts classes on the Russian mass media, the image of Poland in the Russian media, the Eurasian area in media narrative, manipulation in media culture, the ideas and ideologies of modern Russia. Her additional academic interests are the Russian and American model of television; investigative journalism and scientific journalism. E-mail: agata.krzywdzinska@uj.edu.pl 